\title{
Heavy Metals Assessment of Abattoir Effluent on Surface Water Quality of River Katsina-ala of Benue State, Nigeria
}

\author{
Addy Jose Vershima ${ }^{1, *}$, Kabough Jonathan Terkimbi ${ }^{2}$, Azua Terese $^{3}$, \\ Aliyu Ibrahim ${ }^{4}$ \\ ${ }^{1}$ Department of Biological Sciences, P.M.B. 2373, University of Agriculture, Makurdi, Nigeria \\ ${ }^{2}$ Federal Capital Territory Administration Abuja, Nigeria \\ ${ }^{3}$ Department of Biological Sciences, P.M.B. 2373, University of Agriculture, Makurdi, Nigeria \\ ${ }^{4}$ Department of Science Laboratory Technology, Nassarawa State Polytechnic, Lafia, Nigeria \\ *E-mail address: joseaddy1@gmail.com
}

Keywords: River Katsina-ala; heavy metal; effluent; abattoir

\begin{abstract}
Water samples of six sampling sites (two downstream, two abattoir sites and two upstream sites) were analyzed using standard methods to determined and assessed heavy metal content of abattoir effluent on surface water quality of River Katsina-Ala, Benue State, Nigeria for rainy and dry seasons. Rainy season heavy metals results were; $\mathrm{Cr}^{6+}(0.032 \pm 0.06 \mathrm{mg} / 1) ; \mathrm{Mn}^{2+}$ $(0.16 \pm 0.034 \mathrm{mg} / \mathrm{l}) ; \mathrm{Cu}^{2+}(0.86+0.46 \mathrm{mg} / 1) ; \mathrm{Pb}^{2+}\left(0.006 \pm 0.002 \mathrm{mg} / ; \mathrm{Cd}^{2+}(0.0023 \pm 0.004 \mathrm{mg} / \mathrm{l})\right.$ and the dry season results were: $\mathrm{Cr}^{6+}(0.028 \pm 0.007 \mathrm{mg} / \mathrm{l}) ; \overline{\mathrm{Mn}}^{2+}(0.07 \pm 0.05 \mathrm{mg} / \mathrm{l}) ; \overline{\mathrm{Cu}}^{2+}(0.85 \pm 0.16 \mathrm{mg} / \mathrm{l})$; $\mathrm{Pb}^{2+}(0.0030 \pm 0.014 \mathrm{mg} / 1) ; \mathrm{Cd}^{2+}(0.0021 \pm 0.012 \mathrm{mg} /)$. Most heavy metals for both seasons were within the maximum permissible limit set by Federal Ministry of Environment, Nigeria (1991). The mean concentrations of $\mathrm{Zn}^{2+}(1.70 \pm 0.29 \mathrm{mg} / \mathrm{l})$ for rainy season and $\mathrm{Zn}^{2+}(1.33 \pm 0.23 \mathrm{mg} / \mathrm{l})$ dry season were above the control and standard safe limits of $<1 \mathrm{mg} / \mathrm{l} \mathrm{FMEnv} \mathrm{(1991)} \mathrm{for} \mathrm{surface} \mathrm{water} \mathrm{quality.}$ There was no significance difference $(p<0.05)$ between the means from upstream and downstream sites for both seasons; though significance difference $(p<0.05)$ existed at the abattoir sites. River Katsina -ala is slightly polluted. Heavy metal content from effluents from abattoir contributed to upset the physicochemical balance of the river. Bioaccumulation and bio-magnification of heavy metals may occur from prolong usage of the river water for drinking. It is suggested that the abattoir effluent be treated before discharge into the river to reduce environmental and health hazards.
\end{abstract}

\section{INTRODUCTION}

On World Water Day, 2010, UNEP and UN-Habitat launched the report, 'Sick Water- The Central Role of Wastewater Management in Sustainable Development', which shows that an estimated 90 percent of all wastewater in developing countries is currently discharged untreated directly into rivers, lakes or the oceans (UNEP, 2010).

Abattoirs are generally known all over the world to pollute the environment directly or indirectly from their various processes (Adelegan, 2002). Abattoir can be defined as a premise approved and registered by controlling authorities for hygienic slaughtering, inspection, processing, effective preservation and storage of meat products for human consumption (Alorge, 1992). It has also been reported that animals which graze on contaminated plants and drink from polluted waters, as well as marine lives that breed in heavy metal polluted waters also accumulate such metals in their tissues and milk if lactating (Yahaya et al., 2009). The heavy metals present in most Nigerian rivers are found in concentrations well above acceptable and permissible levels: lead, copper, zinc, nickel, chromium, cadmium and iron (Olayinka and Alo, 2004). 
Metals, such as mercury, copper, and zinc are naturally found in the environment; at low concentrations, they are essential for ecosystem and human health. However, extended exposure or exposure at high levels can have serious consequences for humans as these metals tend to bioaccumulation in tissues (UNEP GEMS, 2007). Human activities, particularly the increase in mining and industrial processes since the 19th century, have increased the concentration of metals in the environment (Carr and Neary, 2008). Since fish can accumulate metals, they can contain high concentrations of mercury and expose people to concentrations sometimes tens of thousands of times higher than that found in the water source, posing a serious threat to human health (WHO, 2005). Inhabitants of Katsina-ala town depend mostly on River Katsina-ala as a major source of water. The aim of this study is to assess heavy metals pollution on surface water quality of River Katsina-ala from unregulated discharge of abattoir effluent. Data from this work will aid regulatory bodies monitor anthropogenic activities at the abattoir and create public awareness.

\section{MATERIALS AND METHODOLOGY}

The study was conducted in Katsina-Ala town of Benue State in North Central, Nigeria which lies on latitude $7^{\circ} 10^{\prime} 0^{\prime}$ North and longitude $9^{\circ} 17^{\prime} 0^{\prime}$ East (Google links, 2010). Katsina -Ala abattoir situated at the bank of river Katsina-ala, (Fig.1). Water samples were collected between 7.00-10.00am in November and March for dry season; April and October for rainy season.

\subsection{Determination of heavy metals}

Direct Reading Atomic Absorption Spectrophotometer (DR/2000) was used. A blank of 25ml of deionized water was measured into the sample cell, placed in the cell holder and the light shield closed. The zero key was pressed and the reading displayed $0.00 \mathrm{mg} / \mathrm{l}$. The above procedure was repeated for the sample in three replicates $(\mathrm{HACH}, 1997)$. This procedure was adopted for measuring chromium (programme number (90) and wavelength adjusted to $(540 \mathrm{~nm})$; programme number (295) for manganese and wavelength $525 \mathrm{~nm}$; programme number (145) for copper and wavelength $425 \mathrm{~nm}$; programme number (283) for lead and wavelength $477 \mathrm{~nm}$; programme number (60) for Cadmium and wavelength $515 \mathrm{~nm}$. Data was analyzed the mean concentrations of parameters were compared with Federal Ministry of Environment guidelines for interim uniform effluent limits for all categories of industries in Nigeria (FMEnv, 1991). 


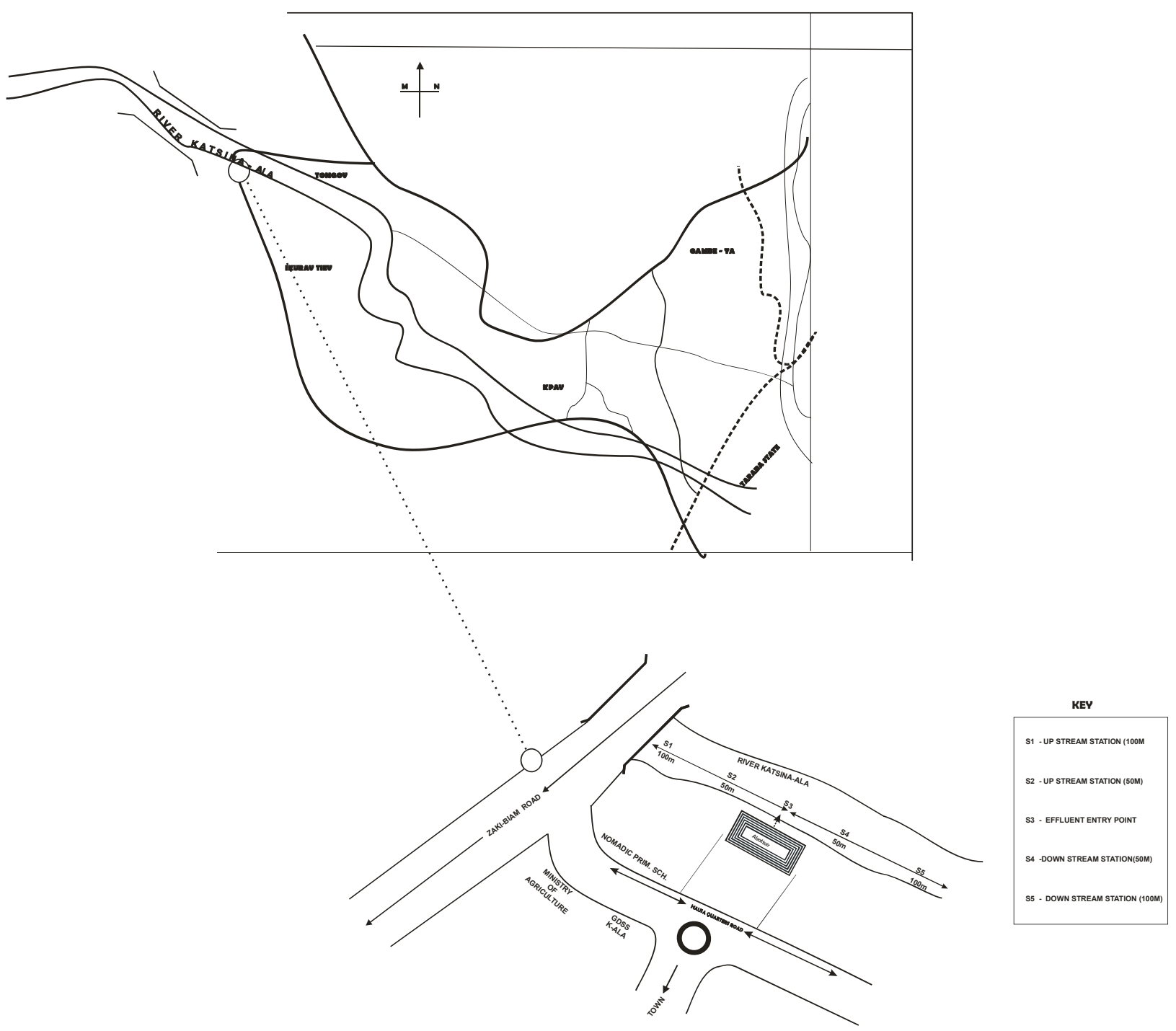

Figure 1. Map of Katsina-ala town showing location of abattoir

\section{RESULTS AND DISCUSSION}

Table 1 presents mean concentration values of heavy metals at the sampling sites for rainy and dry seasons. The mean result of each heavy metal was compared with maximum standard values of Federal Ministry of Environment, Nigeria (Table 2). 
Table 1. Mean heavy metals values from sampling sites

\begin{tabular}{|c|c|c|c|c|c|c|c|c|}
\hline $\begin{array}{ll}\text { Heavy metals } \\
(\mathrm{mg} / \mathrm{l})\end{array}$ & Site 1 & Site 2 & Site 3 & Site 4 & Site 5 & Total & $\begin{array}{l}\text { Mean \& Standard } \\
\text { Deviation }\end{array}$ & $\begin{array}{l}\text { FMEnv } \\
\text { (1991) }\end{array}$ \\
\hline $\mathrm{Zn}^{2+}$ & & & & & & & & $<1$ \\
\hline Rainy season & 0.84 & 0.96 & 1.62 & 1.22 & 1.04 & 5.68 & $1.13 \pm 0.30$ & \\
\hline Dry season & 0.76 & 0.82 & 2.24 & 2.04 & 1.96 & 8.26 & $1.65 \pm 0.79$ & \\
\hline $\mathrm{Cr}^{6+}$ & & & & & & & & 0.05 \\
\hline Rainy Season & 0.01 & 0.02 & 0.04 & 0.03 & 0.03 & 0.13 & $0.026 \pm 0.011$ & \\
\hline Dry season & 0.01 & 0.01 & 0.05 & 0.03 & 0.02 & 0.12 & $0.024 \pm 0.01$ & \\
\hline $\mathrm{Mn}^{2+}$ & & & & & & & & 5 \\
\hline Rainy season & 0.1 & 0.1 & 0.2 & 0.2 & 0.1 & 0.34 & $0.68 \pm 0.08$ & \\
\hline Dry season & 0.01 & 0.01 & 0.03 & 0.02 & 0.02 & 0.09 & $0.018+0.008$ & \\
\hline $\mathrm{Cu}^{2+}$ & & & & & & & & $<1$ \\
\hline Rainy season & 0.28 & 0.34 & 1.22 & 0.82 & 0.64 & 3.30 & $0.66+0.38$ & \\
\hline Dry season & 0.44 & 0.46 & 1.24 & 0.84 & 0.68 & 3.66 & $0.73 \pm 0.32$ & \\
\hline $\mathrm{Pb}^{2+}$ & & & & & & & & 0.05 \\
\hline Rainy Season & 0.002 & 0.004 & 0.007 & 0.005 & 0.005 & 0.02 & $0.0046+0.001$ & \\
\hline Dry Season & 0.0001 & 0.0002 & 0.0034 & 0.0026 & 0.01 & 0.016 & $0.0016 \pm 0.001$ & \\
\hline $\mathrm{Cd}^{2+}$ & & & & & & & & 0.01 \\
\hline Rainy Season & 0.0010 & 0.0020 & 0.0030 & 0.0020 & 0.0020 & 0.01 & $0.0020 \pm 0.007$ & \\
\hline Dry Season & 0.0010 & 0.0014 & 0.0026 & 0.0020 & 0.0016 & 0.01 & $0.00017 \pm 0.0006$ & \\
\hline
\end{tabular}

Table 2. Maximum Heavy Metal Limit by Federal Ministry of Environment, Nigeria

\begin{tabular}{|l|l|}
\hline Variables & Discharge to surface Water \\
\hline Cyanide (as CN-) & 0.1 \\
\hline Arsenic (as As) & 0.1 \\
\hline Manganese (as Mn) & 5 \\
\hline Cadmium, Cd & $<1$ \\
\hline Chromium (trivalent and hexavalent) & $<1$ \\
\hline Copper & $<1$ \\
\hline Lead & $<1$ \\
\hline Mercury & 0.05 \\
\hline Silver & 0.1 \\
\hline Zinc & $<1$ \\
\hline
\end{tabular}

- Not applicable or none set Source: FMEnv, 1991

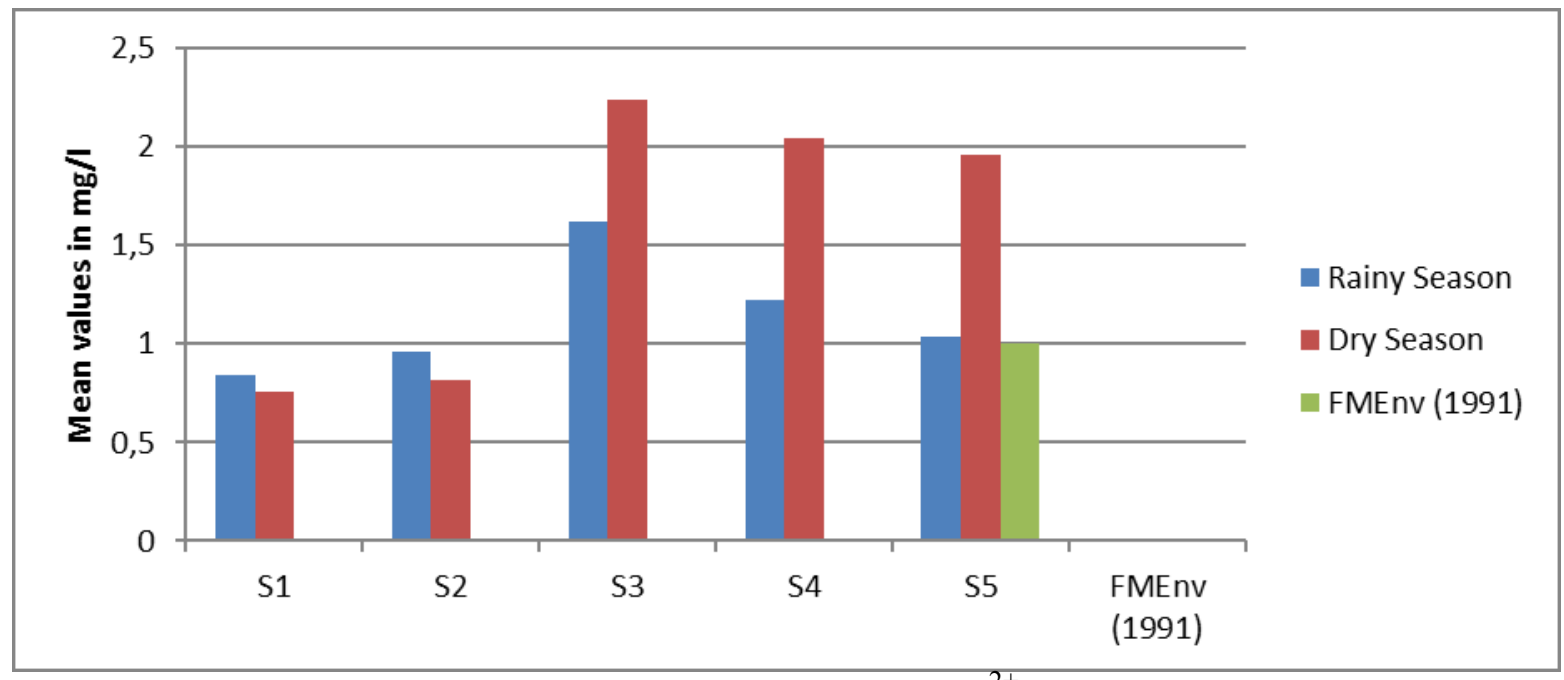

Figure 2. Seasonal variations in zinc $\left(\mathrm{Zn}^{2+}\right)$ concentration 


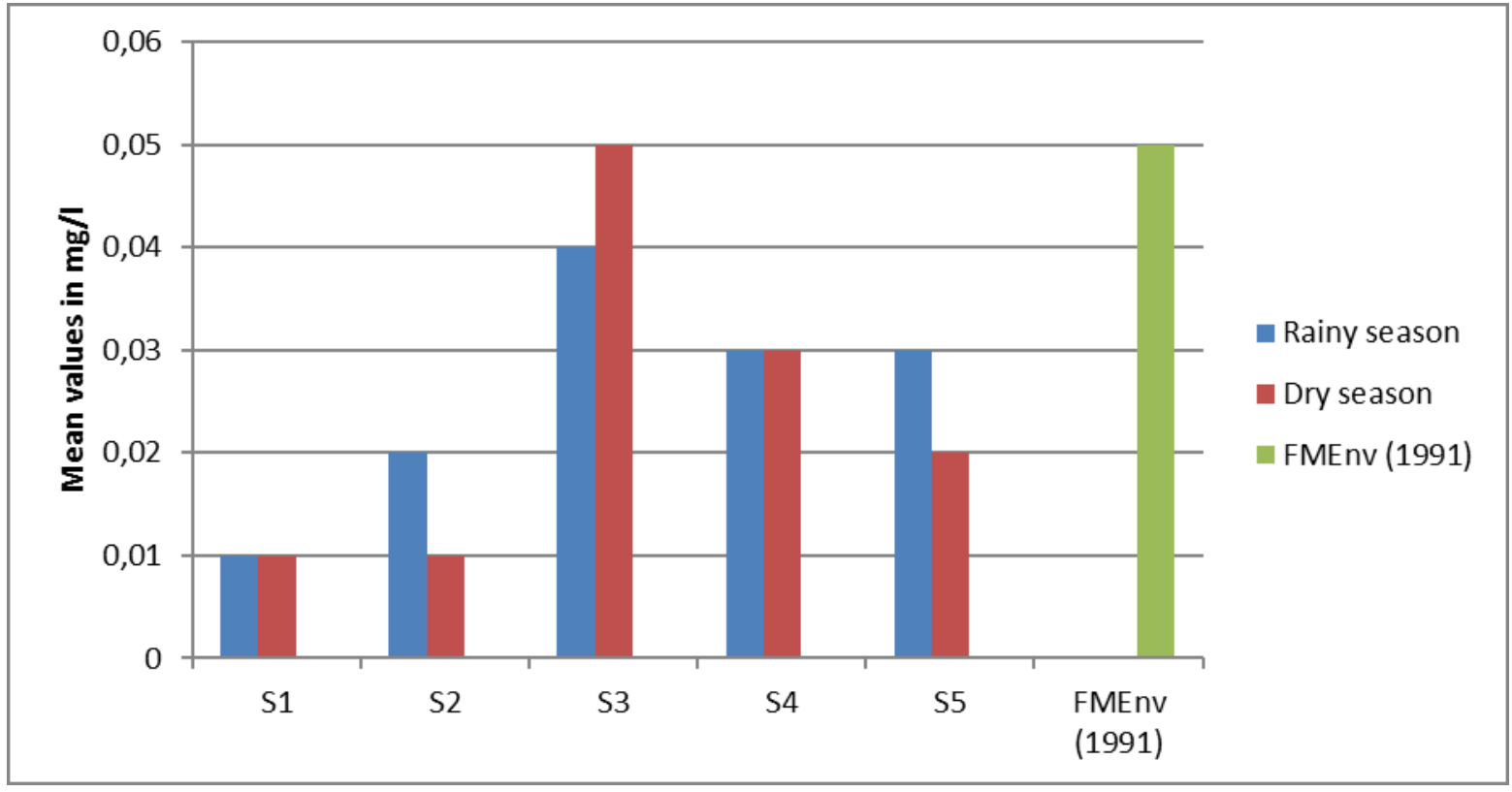

Figure 3. Seasonal variations in chromium concentration

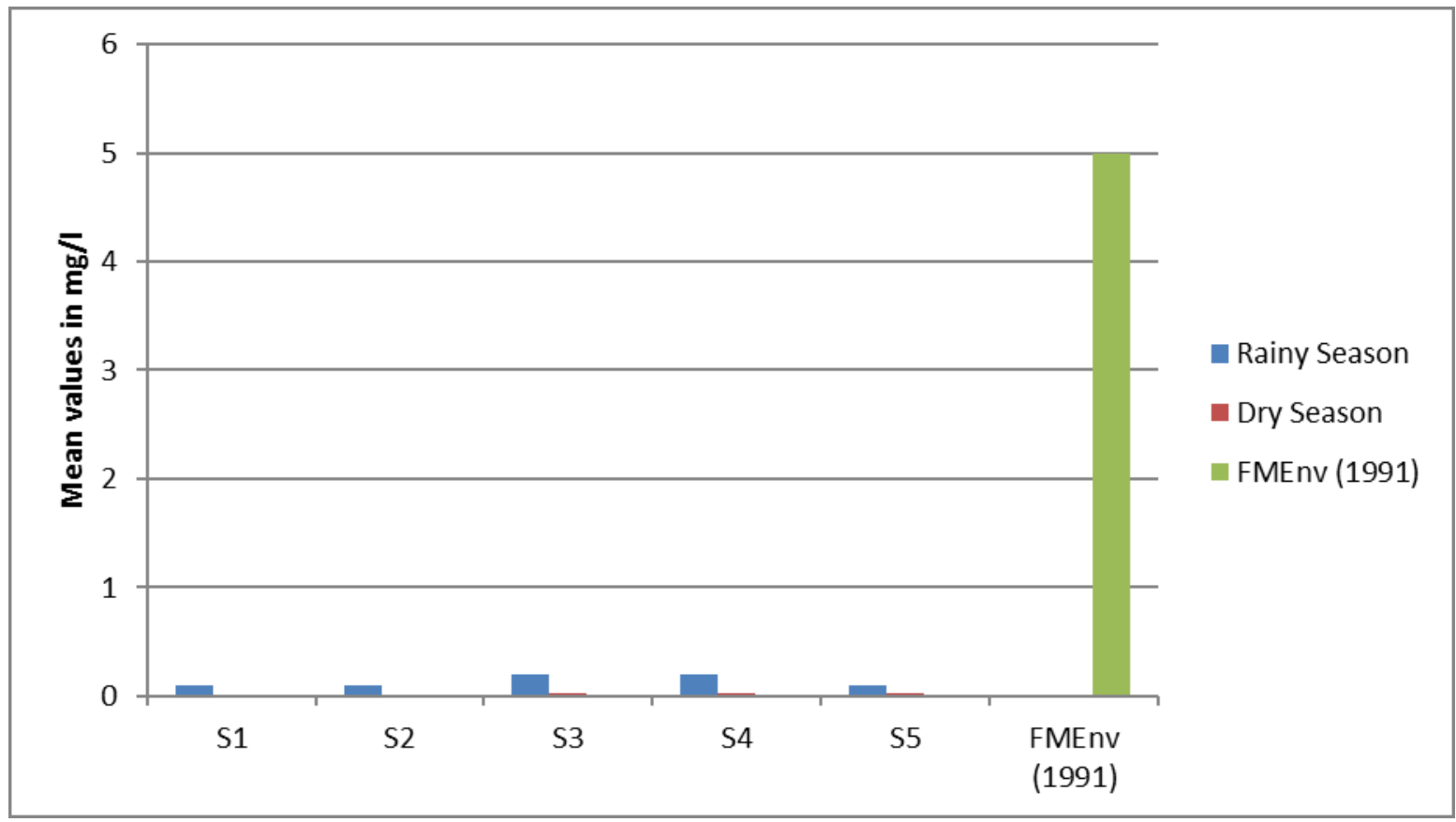

Figure 4. Seasonal variations in manganese concentration 


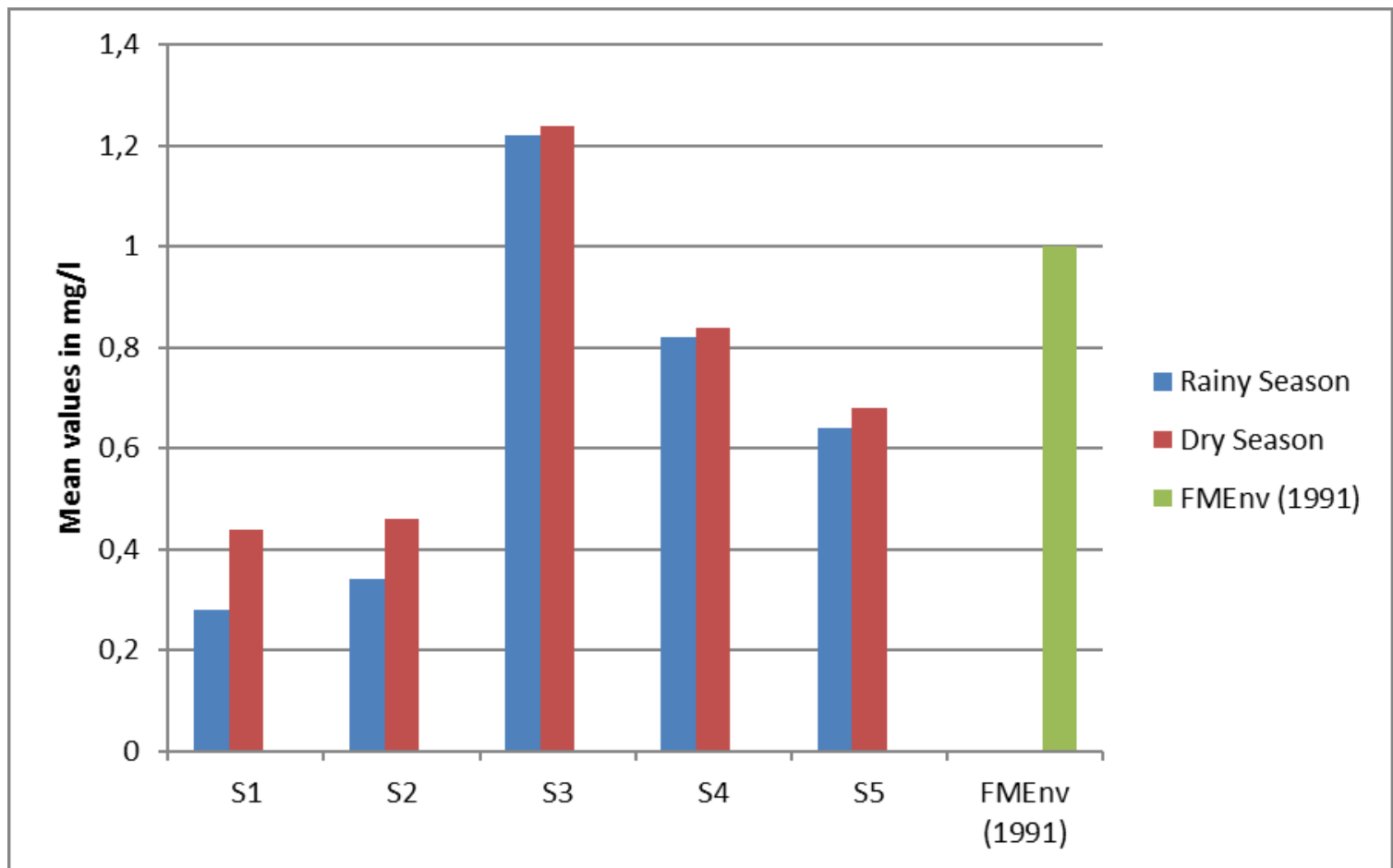

Figure 5. Seasonal variations in copper concentration

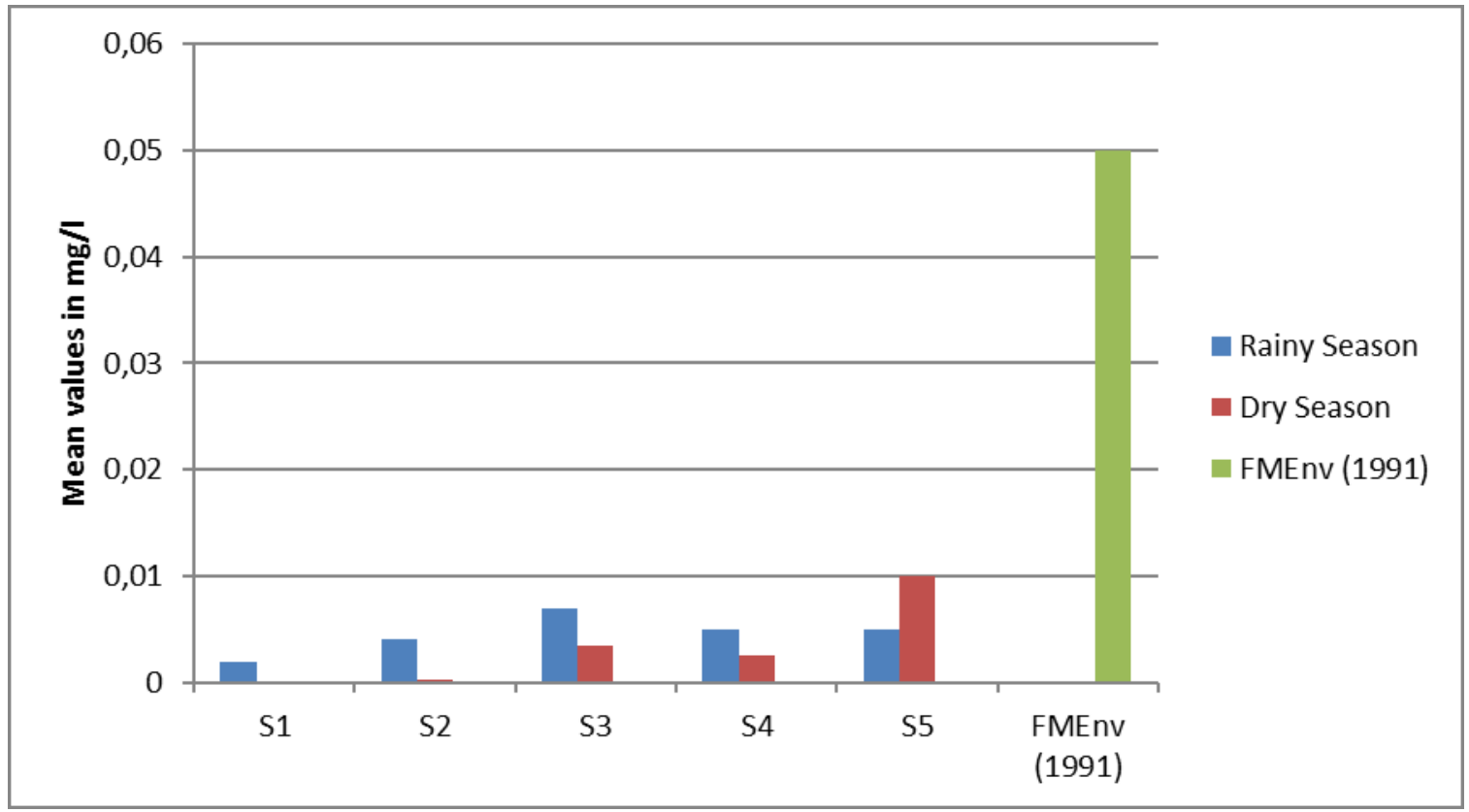

Figure 6. Seasonal variations in lead concentration 


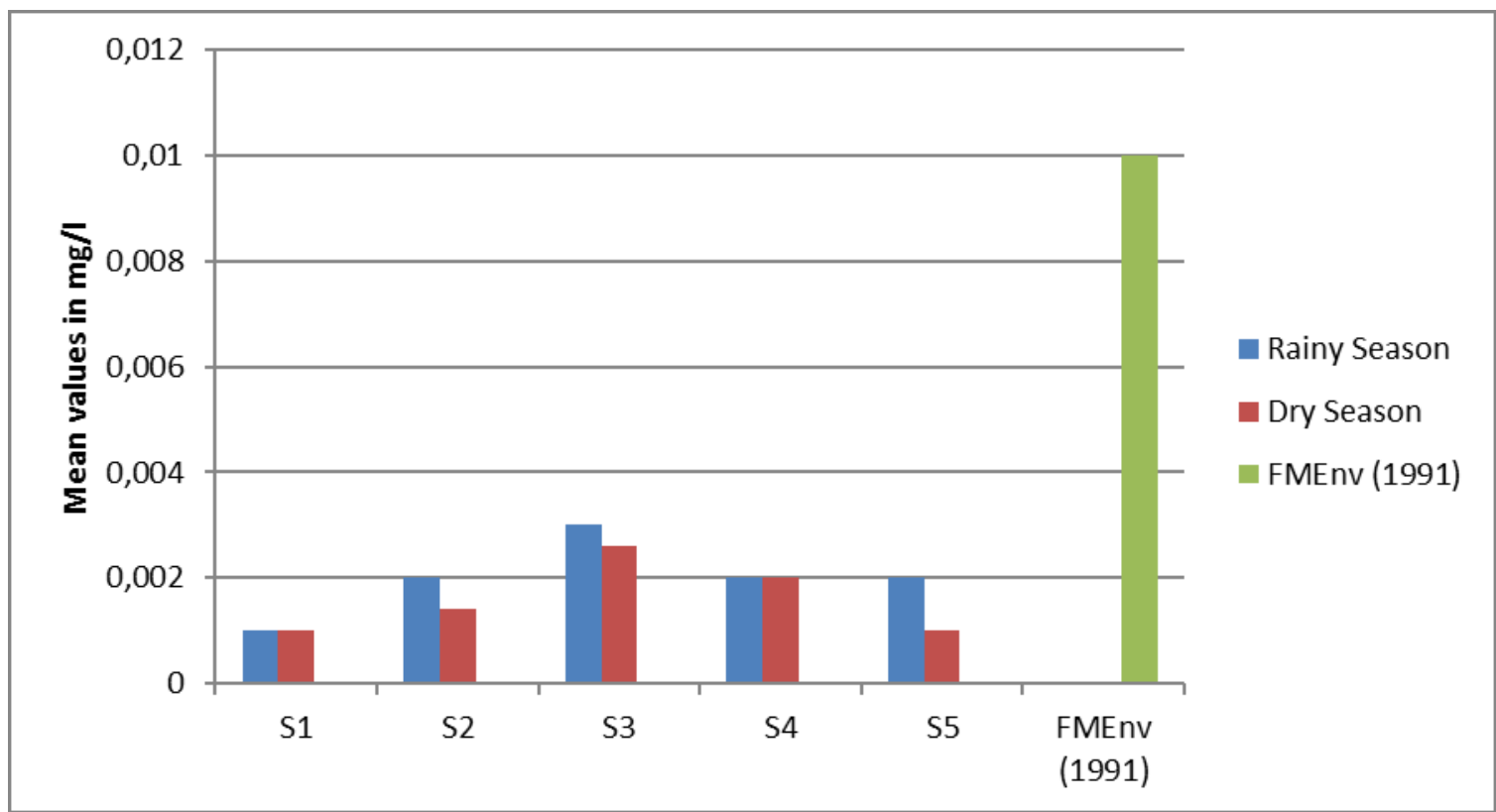

Figure 7. Seasonal variations in cadmium concentration

Zinc is essential element acting as structural component and having specific properties indispensable for life (Bengari \& Patil, 1986). Figure 2 have shown the upstream sites mean values of zinc were within the permissible standard of $<1 \mathrm{mg} / \mathrm{l}$ by FMEnv (1991) while the high mean values for zinc at downstream sites could be due to anthropogenic activities at the abattoir.

Chromium levels at upstream and downstream experimental sites fall within the maximum effluent limit for chromium of 0.05mg/l set by FMEnv (1991) as shown in Figure 3. Chromium can bioaccumulate in tissues of aquatic organisms like fish and may affect humans that are usually at the end of the food chain. This assertion confirms the work of Ayse et al., (2010) on the bioaccumulation of hexavalent chromium in tissues (gill, skin and muscle) of a freshwater fish, Tilapia, Oreochromis aureus. Hexavalent chromium $\left(\mathrm{Cr}^{6+}\right)$ is a well known carcinogen metal form for animals and human beings Ayse et al., (2010). In contrast to Hexavalent chromium $\left(\mathrm{Cr}^{6+}\right)$, the trivalent form of chromium is 500 to 1000 times less active against living cells because of its poor uptake. Heavy doses of chromium salts even though are rapidly eliminated from human body could corrode the intestinal tract (WHO, 2004).

Figure 4 have shown manganese means at all sites in both seasons ranged from $0.068 \pm 0.08$ $\mathrm{mg} / \mathrm{l}$ in rainy season to $0.018 \pm 0.008 \mathrm{mg} / \mathrm{l}$ in dry season were within the permissible maximum limit of $5 \mathrm{mg} / \mathrm{l}$ set by FMEnv (1991). This data fell within the range of reported by Morenikeji (2008) for Alamuyo steam in Ibadan, Nigeria. Manganese is an essential element for humans and plants, but studies suggest that exposure to high levels in drinking water can lead to adverse neurological effects ( Wasserman et al., 2006).

Copper mean values in both seasons ranged from $0.068 \pm 0.38 \mathrm{mg} / 1$ in rainy season and $0.73 \pm 0.32 \mathrm{mg} / \mathrm{l}$ in dry season were within the acceptable limit of less than $1 \mathrm{mg} / 1$ by FMEnv (1991) as shown in figure 5. Although copper is essential for plant growth, a very small amount of copper is required for plant growth. At lower concentrations, copper ions cause headache, nausea, vomiting and diarrhea and at high concentrations they cause anemia, gastrointestinal disorder and also lead to liver and kidney malfunctioning in extreme cases (USEPA, 1999).

Figure 6 have shown the mean levels of lead ions in rainy season higher than lead mean values in dry season. Means at sample sites for both seasons were below the permissible level of $0.05 \mathrm{mg} / 1$ set up by FMEnv (1991). Lead is carcinogenic; apart from causing cancer, interference with Vitamin D metabolism; affect mental development in infants, toxic to the central and peripheral nervous systems (SON, 2007).

Cadmium concentrations at sample stations for both seasons were below maximum of 0.01 $\mathrm{mg} / \mathrm{l}$ set by FMEnv (1991). No significance difference $(\mathrm{p}<0.05)$ was observed in cadmium 
concentration for both seasons. Studies have proved that cadmium is toxic to kidney and liver. Cadmium causes poisoning in various tissues and organs of animals (Yapici et al., 2006).

Table 2 have shown that Chromium, Manganese, Lead and Cadmium mean values at all sampling sites were within the permissible limits of $<1 \mathrm{mg} / 1,5 \mathrm{mg} / 1,<1 \mathrm{mg} / 1$ respectively in both season while the mean values of copper and zinc were both higher than the acceptable limit of $<1$ $\mathrm{mg} / 1$ set by FMEnv (1991) in both seasons.

The global heavy metal pollution of water is a major environmental problem. Among the various toxic pollutants, heavy metals are particularly severe in their action due to tendency of biomagnification in the food chain. The results from this study disagree with the view of (Olayinka and Alo, 2004) that heavy metals present in most Nigerian rivers are found in concentrations well above acceptable and permissible levels. The range of results obtained from this study were consistent with Osakwe (2014) findings that on individual basis, the values for all the metals were in the range that fall within contamination range (less than 1). It has been reported that heavy metals, reaching excessive levels can exert serious impact on humans, animals and plants because they are not biodegradable as they are retained indefinitely in the ecological systems and in the food chain (OmPrakash et al., 2011) . Though the heavy metals are within the maximum allowed limits, they still pose a threat to human health.

\section{Acknowledgement}

The authors acknowledge the assistance received from Water Works Laboratory of Benue State, Nigeria

\section{References}

[1] Alorge DO (1992). Abattoir Design, Management and Effluent Disposal in Nigeria, University of Ibadan press: In; Nwankwoala, H.O.;Pabon, D.; Amadi, P.A. (2009). Seasonal Distribution of Nitrate and Nitrite Levels in Eleme Abattoir Environment, Rivers State, Nigeria. Journal Appl. Sci. Environ. Manage. 13(4):35-38.

[2] Adelegan, J.A., (2002). Environmental policy and slaughterhouse waste in Nigeria. Proceedings of the 28th WEDC Conference, 2002, Calcutta, India, pp: 3-6.

[3] Ayse Bahar, Y1lmaz, Cemal Turan and Tahsin Toker (2010). Uptake and distribution of hexavalent chromium in tissues (gill, skin and muscle) of a freshwater fish, Tilapia, Oreochromis aureus. Journal of Environmental Chemistry and Ecotoxicology Vol. 2(3), pp. 28-33 ISSN 2141 -226X. Accessed $28^{\text {th }}$ March 2015

[4] Bengari, K.V. and Patil, H.S., (1986). Respiration, liver glycogen and bioaccumulation in Labeo rohita exposed to zinc. Indian Journal of Comparative Animal Physiology 4: pp.79-84.

[5] Carr, G.M. and J.P. Neary. (2008). Water Quality for Ecosystem and Human Health, $2^{\text {nd }}$ Edition. pp 45-53

[6] Federal Ministry of Environment, Nigeria (1991). National Guidelines and Standards for water quality in Nigeria, pp 114

[7] Google links (2010). Google links for Map of Katsina-Ala local government, Benue-Nigeria http://www.googlelinks.com Accessed on $30^{\text {th }}$ February, 2015

[8] HachWater Analysis Hand book (1983). Loveland Colorado. pp. 181-278. http://dx.doi.org/10.1016/j.ecoenv.2006.01.005: $\quad$ PMid: 16551477. http://dx.doi.org/10.1016/S0378-4274 (96)80302-X

[9] Morenikeji 0.A. and Raheem N.K. Impact of abattoir effluents on surface waters of the Alamuyo stream in Ibadan J. Appl. Sci. Environ. Manage. March, 2008 Vol. 12(1) 73 - 77 
[10] Olayinka KO and Alo BI (2004). Studies on industrial pollution in Nigeria: the effects of textile effluents on the quality of groundwater in some parts of Lagos. Nigeria Journal of Health and Biomedical Sciences. 2004. 3(1): pp. 44-50.

[11] OmPrakash M, Ashish G, Mahipatsingh, Rajayashree P (2011) Determination of Toxic Trace Metals $\mathrm{Pb}, \mathrm{Cd}, \mathrm{Ni}$, and $\mathrm{Zn}$ in Soil by Polarographic Method. International Journal of Chemical Technology Resources 3(2): 599-604. CODEN (USA): IJCRGG ISSN: 0974-4290

[12] Osakwe Stephen Anapuwa (2014) Heavy Metal Contamination and Physicochemical Characteristics of Soils from Automobile Workshops in Abraka, Delta State, Nigeria International Journal of Natural Sciences Research, , 2(4): 48-58

[13] Standard Organization of Nigeria (2007). Nigeria Industrial Standard. Price group D Operational headquarters, Lagos,Nigeria. p.49

[14] United Nations Environment Programme Global Environment Monitoring System (2007).Water Quality Outlook .http://esa.un.org/iys/docs/san_lib_docs/water_ quality_outlook.pdf. (Retrieved February 28, 2015)

[15] United Nation Environment Programme (UNEP) 2010 World water day 2010 highlights solutions and calls for actions to improve water quality worldwide http://www.unep.org http://www.animalscience.tamu.edu/ansc/publications/beefpubs/L5176- framescore.pdf

[16] USEPA (1999) Natural primary drinking water regulation. United States Environmental protection Agency, 1999.

[17] Wasserman, G.A., X.H. Liu, (2006). Water Manganese Exposure and Children intellectual Function in Araihazar, Bangladesh. Environmental Health Perspectives 112:1329-1333.

[18] World Health Organization (WHO)(2005). Mercury in Drinking Water pp.33-41 http://www.who.int/water_sanitation_health/dwq/chemicals/mercuryfinal.pdf. Accessed $9^{\text {th }}$ March.2015

[19] Yapici, G., I.H.G. Timur and A. Kaypmaz, (2006). Lead and cadmium exposure in children living around a coal-mining area in Yatagan, Turkey, Toxicology Industrial Health, 22: 35762.

[20] Yahaya M.I, Mohammed S, and Abdullahi, B.K (2009) Seasonal Variations of Heavy Metals Concentration in abattoir Dumping Site Soil in Nigeria. Journal of Applied Science Environment and Management 13(4):9-13. 